\title{
USE OF LEADER'S READING CHALLENGE METHOD IN IMPROVING READING INTEREST FROM TOURISM AWARENESS GROUP (TAG) STONE GARDEN OF WEST BANDUNG REGENCY THROUGH COMMUNITY READING PARK (CRP)
}

\author{
Mardiah \\ IKIP Siliwangi \\ mardisyakir@gmail.com
}

\begin{abstract}
Indonesian reading culture is very low. Various ways to increase interest in reading have been done by the government. Reading Reading Movement, National Movement of Literacy of Nations has been regulated in Law no 43 of 2007 and Permendikbud No 23 year 2005. In support of the program, this research is conducted in Community Literacy Movement by Leader's Reading Challenge (LRC) method. This initiative is a form of Community Empowerment in Tourism Awareness Group (TAG) Stone Garden of West Bandung regency. The study titled Use of Leader's Reading Challenge (LRC) Method in Improving Reading Interest of Tourism Awareness Group (TAG) of West Bandung Regency through Community Reading Garden. LRC is a method used from South Australia namely Premier Reading Challenge (PRC). The method used is descriptive qualitative research. By taking observation data, interviews, questionnaires, literature studies and documentation. Initial Conditions of the people who studied have low interest in reading because many factors cause. It is very influential is the low education, low economic and less facilitated to read and no activities of literacy movements in these tourist attractions. So after the research done, it appears the increase of reading interest with the indicator, reading activities in Community Reading Park (CRP) or in the tourist spot when .The indicator of reading success is that there has been the number of books read, there has been a review made also the existence of tree literasi. Internal factor which become indicator of success is with data of result of questionnaire expressing happiness after reading book. They feel happy with LRC Literacy activity. Constraints certainly exist, which is still a lot of interesting books to read, there are still activities that encourage people to motivate reading fond. There is still much more role and support from the government and the wider community in providing funds and also providing the means to manage Community Reading Gardens and the management of tourism literacy groups.
\end{abstract}

Keywords: Empowerment, Tourism, Literacy, Reading Interest.

\section{INTRODUCTION}

According to Rahim (in Periyeti 2017: 55-66) reading will improve the quality of society or nation. He mentioned that "the low interest of reading the community, greatly affect the quality of the nation. Because of the low interest in reading, can not know and issues 
of science and information development in the world. Where will ultimately affect the backwardness of the nation itself ".Based on the survey below shows that Indonesian people do not like to read. The reading result of Indonesian reading interest is only $0.001 \%$ or one to 1,000 (Erwina, W. 2014: 23-40). This is a problem, because in Nurul Hayati-Yoyon Suryono (2015: 175-191), that the low reading interest in Indonesia is a common problem that has been solved together as well. Today, culture is read by the public media more than the tantalizing features. Based on a five-day study Progress in the International Reading Literacy Study (PIRLS) Indonesia uses 36 out of 40 countries. This condition is very ironic and needs to be a benefit of activists engaged in this field.

A lot of government efforts in increasing reading interest of the community. For example, the Reading Reading Youth Program, supporting the availability of cheap books, the growth of community reading parks regulated in the Law of the Republic of Indonesia No.43 of 2007 Article 48. This is corroborated by Permendikbud No. 23 of 2015 on the growth of character. One of its activities is the School Literacy Movement (GLS) on formal education and the Community Literacy Movement (CLM)). Thus, literacy programs or literacy, its merits only to read and grow, but can improve the lives of Ansori Al-B community (2012: 47-61)

With the aim of increasing the reading interest of RW 09 Community of Giri Mukti Village Citatah Subdistrict, this research continued with the formulation of problem "How Leaders' Method Reading Challenge (LRC) can increase reading interest of tourism group (TAG) Garden Stone Kabupaten Bandung". By adding a description of the initial conditions and the unity it faces.

\section{THEORETICAL BASIS}

According to Tarigan, interest in reading is the ability of a person to communicate with himself to capture the meaning contained in the writing so as to provide emotional experience as a result of a form of deep attention to the meaning of reading. While Tampubolon reveals that interest in reading is an incentive to understand the word for word and the content contained in the text, so that readers can understand the things that are poured in the reading, Dalman (2014: 141). Furthermore it is said that interest in reading is a strong and deep attention accompanied by feelings of pleasure towards the activity of reading so as to lead a person to read with his own volition or encouragement from the outside. Interest in reading is also a feeling of pleasure someone to read because of the thought that with reading it can be obtained benefit for him. Herman Wahadaniah (in Al Musafiri, M.2017: 110-122).

Tourism Awarness Group (TAG)) according to Ir. Firmansyah Rahim The Director General of Tourism Destination Development of the Ministry of Tourism and Creative Economy 2012 is one of the components in society that has an important role and contribution in the development of tourism in the region, the existence of TAG should be supported and nurtured so that it can play a more effective role in participating in mobilizing participation communities to create an environment and atmosphere conducive to the growth and development of tourism activities around tourism destinations

In the National Literacy Movement guidebook issued by the Center for Development and Development of Language Language Ministry of Education and Culture in 2016, 
states that literacy can be interpreted as literacy, namely the ability of a person to read and write. A person is said to be literate if he has knowledge in every activity that demands effective literacy function in society. Knowledge gained through reading and writing can be utilized for self and nation progress.

So in this study, using a method of literacy called Leader's Reading Challenge (LRC). The way and techniques are referred to the literacy developed in West Java, West Java Leader's Reading Challenge (WJLRC). Thus, in the WJLRC Guidebook compiled by West Java Provincial Government of Education Office 2016. Explain that WJLRC is defined as a reading challenge aimed at teachers and students at schools from leaders in West Java. Leaders referred to in this activity are the highest government leaders in a region can the principal, lurah, sub-district, regents, mayors. governor to president.

LRC method in increasing reading interest of TAG Stone Garden community, need basic means, that is book. Then its existence needs a proper vehicle that is the community reading park (CRP)). The existence of TBM has been regulated in the Law of the Republic of Indonesia No.43 of 2007 on Library Article 49 which explains that the government, local government, and the community encourage the growth of reading and reading houses to support reading culture. It further explains that community reading park (CRP) is an institution that provides various types of learning materials needed by the community. As a place to build literacy and learning, as well as a place to get information to the public (Ministry of National Education, 2008). The reading garden is a source of information for the community, both the people and the middle and upper middle class communities. Starting from the placement of RW, Village, recreation area, city garden and others. Very effective, efficient and affordable for all people. Dewi: 2010 (in M.Arif Khoiruddin .2016: 291-319)

\section{RESEARCH METHODS}

This research uses qualitative approach with descriptive method. This approach examines the condition of natural objects, as they are, not manipulated so that the conditions at which the researcher enters the object, and after being in the object or after exiting the object, is relatively unchanged

In this study, the subject of research is the community RW 09 Kampung Giri Mulya Desa Gunung Masigit District Cipatat West Bandung regency. They are incorporated in the Stone Tourism Awareness Group (TAG)) which amounts to about 120 people.

The research instruments are observation sheet, interview sheet, questionnaire. Questionnaire was given to the research subjects to explore further about the growing interest in reading within the individual. Contains 10 questions concerning indicators of reading interest. Data collection techniques used in this study are tailored to the needs of qualitative research that is observation, interviews, questionnaires, documentation studies, and literature study.

Data analysis using Spradley Model consisting of: descriptive observation, domain analysis, focused observation, taxonomic analysis, selected observation, component analysis, and ending with theme analysis. 


\section{IV.RESEARCH RESULT AND DISCUSSION}

\section{A. Results of the Research}

\section{SWOT Analysis.}

The objective conditions of the research subjects can be illustrated by SWOT analysis. In terms of strength, the tourist sites managed by TAG are a form of community empowerment that has kept fossils of marine animals 20 million years ago. It has three advantages: archeology, scholarship and beauty charm so often used for student research, prawedding or photographer. Has been the 2nd National Champion in TAG empowerment management in September 2017.

Its former peasant communities and limestone miners with low economic and education are a disadvantage. Education, $80 \%$ of primary and drop out graduates and $20 \%$ of high school graduates and incomes rely only on daily admission tickets.

Tour Stone Garden has a very high chance to develop in photography and geology and archeology. While threats that can weaken TAG are land issues that are still private property, ape communities that threaten the cleanliness, security and beauty of tourism and community knowledge about tourism is still low.

\section{Initial Condition of Reading Interest and Its Causes}

Initial conditions, reading interest Pokdarwis still low. Spare time is more used to chat or play gadgets. The low interest in reading is determined by the lack of cheap book supplies, the absence of a community reading park (CRP) that provides reading facilities. In addition, low education and a weak economy that greatly affects the low interest in reading the community. So that causes them to prioritize earnings in meeting the needs of everyday rather than having to read a book.

\section{The LRC method of increasing interest Read through TBM}

The first step in the activity is the approach to the community. The first step is to personalize the leader of the Pokdarwis and the board. Furthermore, other communities are easier to do because the core management already has a strong desire and motivation in literacy activities and book procurement. Preparing books as a source of reading is collected from various donors. until there are about 500 books available. Types of books available are picture children's stories, teen novels, rock history, agriculture, farming and creative economy.

Determine the challenger of literacy activities ie leaders who will reward participants who have passed the challenge of reading the book should be done. Also because the book has a lot of it requires building a community reading park (CRP). After that, the next step to carry out literacy activities with the Leader's Reading Challenge (LRC) method. Running time for (8 weeks) December 2017 - March 2018. Routine activities in the form of reading a book as much as one fruit in one week. Creating a book review of fishbone (fish spikes containing $5 \mathrm{~W}+1 \mathrm{H}$ ) and Reason of Wisdom Content (RWC), conducting presentations and book discussions and compiling a literacy literature tree and prize at the end of the event for the leader's challenge.

\section{The results obtained, reading interest Pokdarwis increased by LRC method}


The results achieved after the activities of literacy with the LRC method in the Stone Garden tourism literacy group can be proved by two forms, namely extrinsic and internal forms. External forms of reading books, written reviews, discussion activities and the presence of literacy movements. Then the data collected in the form of bills. While the form of interest that is internal, within the subject of research. This is hard to see, so the data collection should use a questionnaire filled by the subject of the study.

The result of reading interest from the questionnaire to explore the inner selfmotivation. This indicates an increase in the frequency of reading a book, the opportunity to read more books, get motivation, feelings of happiness after reading and feel the benefits after reading the book. Increased interest in reading can be shown also by the desire to invite others to read.

\section{Constraints faced in the implementation of LRC in increasing reading interest through CRP.}

Constraints faced from within is derived from the subject of research. Youth have not been maximally in the habit of reading books because of the influence of very strong family conditions to form characters. The low economic problems cause adults to focus more on meeting the need to earn an income at a tourist spot than reading a book.

Obstacles that come from outside the subject of research is the lack of supreme leader's support power to give gifts as motivation to increase reading interest. Other obstacles, such as inadequate facilities, the lack of interesting book supplies, CRP has not been able to accommodate members, and there is still a lack of community literacy movement supported by tutors or facilitators.

\section{B. DISCUSSION}

The initial condition of reading interest in Pokdarwis is very low because it is caused by many factors, such as low education and economic problems, facilities that support reading activities ie the absence of book supplies, the absence of places that provide books such as mobile libraries or CRP and the absence of an activity literacy at tourist attractions. This is as explained by Bunata (in Dalman.2014: 142-144) that the interest in reading a person is influenced by several factors namely: 1). Family environmental factors 2). Community infrastructure factors that are less support for increased reading interest of the community 3) Factors of existence and reading materials and 4) School curriculum and less conducive school. By observing the expert opinion above and looking at the data, it is clear that the Pokdarwis community has a low interest in reading because it is influenced by internal and external factors.

LRC with programmed activities so that it can be said as a planned method, has a form of activity stages of reading books, making book reviews, the presentation of book discussions, the activity to create a literacy tree. So that LRC can be said as a method that can achieve the goal of increasing interest in reading as according to Sanjaya, W (2016: 7-8) explains that the method is the way used to implement the plan that has been prepared in real activities so that goals can be achieved optimally. This means the method is used to realize the established strategy. Thus, the methods in the learning system series play a very important role. The success of learning strategy implemnetasi is very dependent on the way teachers use learning methods, because a learning strategy may only be implemented through the use of learning methods. 
Literacy activities in LRC methods that have been applied to the community with reading, writing reviews, discussions and presenting have been able to increase reading interest. Having formed the habit of literacy then the potential of society will emerge so that they will have achievement. As Strickland says in Yuliyati (2014: 117-126). balance literacy is a framework designed to help all students learn to read and write effectively. The program is based on the concept that all children can learn to read and write. Balancing between reading and writing gives students a chance to succeed. Students receive lessons according to their potential and abilities and adjust the material that is difficult for them to be easy to learn.

After the research subject completes complete reading according to the number determined by the leader, ie one fruit in one week, then the members of the literacy will get a reward. The gift giving has been able to increase the reading interest of the members as according to Hashim in Dalman (2014: 147) explains that gift giving will enlarge the spirit of reading. A response is generated by the stimulus. Reward is a stimulus. Reward is one stimulus to cause a response in children to be more active reading.

Prior to the study, the initial condition of reading interest was low and after the LRC method was applied causing increased reading interest. So the LRC method has been able to increase reading interest among TAG members. Thus LRC is a motivation and encouragement for people who come from within or outside themselves. Because according. (Ruswandi, 2013: 134-135). Motivation can be interpreted as an attempt to cause or increase the drive in an effort to realize the behavior directed to the achievement of a goal. In various theories of research, there is a close connection between the satisfaction achieved in learning with performance and motivation. Satisfaction obtained by students from the learning process, can increase learning motivation. In this case, should be created an atmosphere of learning that can provide satisfaction in order to produce effective learning. Factors that affect student satisfaction in learning, among others, the benefits of learning outcomes, a sense of security in learning, adequate learning conditions, opportunities for self-expansion, or personal relationships.

The existence of Community Reading Gardens that have supported LRC activities to increase reading interest, this is strongly supported by research conducted by M.Arif Khoirudin (2016: 291-319) that the community reading park (CRP) is an institution that provides various types of learning materials needed by the community. As a place to build literacy and learning, as well as a place to get information to the public (Ministry of National Education, 2008). The reading garden is a source of information for the community, both the people and the middle and upper middle class communities. Starting from the placement of community units, villages, recreation areas, urban and other gardens. Very effective, efficient and affordable for all people.

From the results of questionnaires obtained, it has been illustrated that the existence of LRC activities conducted in the tourism area, has changed the hearts, feelings, thoughts and views of research subjects. Thus, literacy activities with the LRC method caused the research subjects to often read books while on duty at tourist attractions. They are happy and happy about LRC activities, CRP and books at work. So they feel the benefits after reading the book and even the desire to invite others to read the book. Can be a clear picture that, LRC has been able to increase interest in reading books. As Herman 
Wahadaniah points out in Al-Musafiri, M (2017: 110-122) that reading interest is a strong and deep concern is accompanied by a feeling of joy in reading that can lead a person to read by his own volition or external encouragement. Interest in reading is also a feeling of pleasure someone to read because of the thought that with reading it can be obtained benefit for him.

With increasing interest in reading, it can also improve attitudes, skills in the field that must be controlled by the community in charge of developing the tour, as experienced by TAG Stone Garden. Because reading a book is the basis for various activities such as Odendahl, W (2017: 209-226) argues that while reading, mathematics, and natural science are indeed important tools for generating constructive, engaging, and reflective citizens, they can only seen as an indirect part of the basis for attaining such enlightened citizenship. It says that, without reading, it is impossible to obtain a world view maintained by literature, art, music, and ethics. In other words, PISA really tests the foundation on which citizenship can be built, while suggesting to measure the whole building.

Various obstacles have been found in this study because the interest of reading is influenced by many factors. The constraints that have been found are due to the low economic and educational, age and facilities available as according to Harris and Sipay in Al-Musafiri, M (2017: 110-122) stated that interest in reading is influenced by personal factors that are factors that originate within the individual itself includes: age, gender, intelligence, reading ability, attitude, psychological needs.

LRC activities in TAG is one of the community empowerment activities where the success of achieving the goals is determined by the condition of the society itself because according to Fitriana, W. (2015: 58-66) states that the focus of community empowerment activities is in the hands of the community itself with a starting point from the community, implemented by the community and its benefits to the community or in other terms community based education. This is one way to build a sense of belonging and responsibility in building and developing empowerment programs within the community.

The LRC method has been able to increase the reading interest of Batu Garden's tourism conscious group with a literacy activity. Thus, it can be argued that the LRC is a form of community education that can be further developed in other offshore education. Because according to Kartika, P. (2015: 50-57) that various educational activities outside of school (community education) can take on forms such as literacy programs, cultural activities such as music, dance or drama, sports activities, popular education and various contexts.

In order to improve the reading culture and develop the school as a learning organization, the ministry of education and culture developed the School Literacy Movement (SLM). SLM aims to make the school as a learning organization so that the citizens of the school can become lifelong learners and can fulfill their role in the information technology era (Effendi, R.2016: 109-117). In West Java GLS was developed with West Java Leader's Reading Challenge (WJLRC) and in this research has been applied in Leader's Reading Challenge (LRC) so that LRC method in TAG

Stone Garden is a form of learning innovation. In the activity there has been interaction between companion and learner done with a planned and gradual to achieve the goals 
to be achieved as according to Mulyana, E (2008: 17) that Learning can be given as any systematic and deliberate effort to create conditions for learning activities to learn. In this activity there is an educative interaction between two parties that is between learners (residents of learning) who do learning activities with education (learning resources) that do activities membelajarkan. Thus learning activities occur as a result of learning activities.

\section{RESEARCH FINDINGS}

The results of the study under the initial conditions of reading interest TAG Stone Garden, that interest in low reading that is influenced by two factors, are internal and external factors of the individual. The internal factor is the family, that is, the economy and the low education. While the ektern factor is adanay facility factors that are book availability, reading garden and reading activities.

LRC activities can remind reading interest visible from the activities of reading books, making reviews, discussions, making literacy trees, the existence of books, the existence of community reading parks built in tourist attractions. The questionnaire results recognize an increased interest in reading.

Obstacles encountered in the present from within the subject of research caused by family factors. Subjects are more concerned about earning a living because of economic needs than reading books. also came from outside of the lack of support of government motivation and still lack of intensive book for participants.

\section{BIBLIOGRAPHY}

Al-musafiri, M. (2017). Pengaruh Minat Baca Mahasiswa Terhadap Hasil belajar pada mahasiswa Jurusan Bimbingan konseling Islam IAI Darussalam Blokagung banyuwangi. Darussalam, Jurnal Pendidikan Komunikasi dan Penelitian Hukum islam , 110-122.

Ansori Al-B. (2012). Proses pembeljaran Pendidikan Keaksaraan Berbasis keluarga di pusat kegiatan belajar Masyarakat Kandaga Desa mayang Kecamatan Cisalak Kabupaten Subang. Empowerment Vo.1 No.1, 47-61.

Ardiwinata, J. S., \& Mulyono, D. (2018). Community Education in the development of The Community. Empowerment, 7(1), 25-35.

Dalman. (2014). Keterampilan Membaca. Depok: PT.Rajagrafindo Persada.

Effendi, R. (2016). Model Pembelajaran SQ3R Untuk Mengembangkan Kemampuan Literasi Matematis Siswa. Jurnal Pendidikan Matematika, 109-117.

Erwina, W. (2014). Berbagai Peranan Perpustakaan dan Taman Baca. Edulib vol.1. no2, 23-40.

Fitriana, W. (2015). Revitalisasi Peran pendidikan Luar Sekolah Dalam Pemberdayaan Masyarakat. Empowerment Volume 3, 58-66.

Kartika, P. (2015). Optimalisasi Peran Masyarakat Dalam Pemberdayaan Masyarakat Melalui Pendidikan Luar Sekolah. Empowerment volume 3, 50-57 
M.Arif Khoirudin-Imam Taulabi-Ali Imran. (2016). Menumbuhkan Minat baca Sejak Dini di Taman Baca Masyarakat. Journal An-Nafs Vol.1 no 2, 291-319.

Mulyana, E. (2008). Model Tukar Belajar. Bandung: Alfabeta.

Nurul Hayati-Yoyon Suryono. (2015). Evaluasi Keberhasilan Program Taman Bacaan Masyarakat Dalam Meningkatkan Minat Baca Masyarakat di daerah Istimewa Yogyakarta. Jurnal Pendidikan dan pemberdayaan Masyarakat Volume 2 nomor 2, 175-191.

Odendahl, W. (2017). Bildungskrise - PISA and the German Educational Crisis. IAFOR Journal of Education Volume 5 - Issue 1, 209-226.

Periyeti. (2017). Usaha meningkatkan Minat Baca Mahasiswa. Jurnal Pustaka Budaya Vol.4. No.1, 55-66.

Ruswandi. (2013). Psikologi Pembelajaran. Bandung: Cipta Pesona Sejahtera.

Sanjaya, W. (2016). Strategi Pembelajaran Berorientasi Standar proses Pendidikan. Jakarta: Prenada Media.

Yuliyati. (2014). Model Budaya Baca-Tulis Berbasis Balance Literacy dan Gerakan Informasi Literasi di SD. Jurnal Ilmu Pendidikan Jilid 20 No.1, 117-126. 